Slađana N. Zuković

DOI: 10.19090/zop.2016.25.99-113

Univerzitet u Novom Sadu,

UDC: $159.913: 364$

Filozofski fakultet

364.442.2:159.9

Pregledni rad

\title{
KARAKTERISTIKE I KLJUČNI FAKTORI EFIKASNOG SAVETODAVNOG RADA ${ }^{1}$
}

Apstrakt: U radu se ukazuje na kompleksnost i specifičnost savetovanja kao profesionalne delatnosti, te ističe važnost sagledavanja pretpostavki efikasnog savetodavnog rada. U tom smislu, u tekstu je dat osvrt na osnovne karakteristike i ciljeve savetovanja kao procesa koji je usmeren na osnaživanje pojedinaca ili grupa da sopstvenim aktivnim delovanjem promene svoje životne situacije i unaprede svoje resurse. Poseban akcenat stavljen je na analizu dva faktora koja su ključna za efikasnost savetodavnog rada, a to su - korisnik savetovanja, tj. pojedinac ili grupa sa svim svojim potrebama, motivima, očekivanjima i ciljevima, i savetnik, tj. stručnjak sa svim osobinama ličnosti, znanjima i veštinama. Pritom se naglašava da efikasno savetodavno delovanje nije moguće bez uspostaljanja pozitivne emocionalne klime i adekvatnog odnosa između savetnika i korisnika savetovanja. Imajući u vidu da savetovanje ne daje model rešenja, već potpomaže oslobađanje potencijala ličnosti koji su blokirani, u zaključku se ističe važnost izbora adekvatnog pristupa u savetodavnom radu, kao i važnost uspostavljanja podržavajuće atmosfere koja će korisniku savetovanja pružati osećaj zadovoljstva, prihvaćenosti i sigurnosti u savetodavnom procesu.

Ključne reči: savetovanje, korisnik savetovanja, savetnik, kompetencije za savetodavni rad.

\footnotetext{
${ }^{1}$ Rad je nastao u okviru projekata „Kvalitet obrazovnog sistema Srbije u evropskoj perspektivi“ (179010) i „Pedagoški pluralizam kao osnova strategije obrazovanja“ (179036) koje u periodu od 2011. do 2016. godine finansira Ministarstvo prosvete, nauke i tehnološkog razvoja Republike Srbije.

Slađana Zuković, sladjana.zukovic@ff.uns.ac.rs
} 


\section{Uvod}

Savetovanje predstavlja teorijski naučno utemeljenu i planski osmišljenu profesionalnu delatnost koju obavlja osoba koja je za takav rad posebno osposobljena u domenama različitih nauka i naučnih disciplina sa čijih pozicija polazi (psihologija, pedagogija, medicina, pravo, itd). Najopštije posmatrano, savetovanje se određuje kao proces pružanja pomoći i podrške pojedincima ili grupama da bolje razumeju svoje vlastite probleme i mogućnosti, da bolje upoznaju sebe, da dođu do određenih uvida, te da postignu određene promene u svojim uverenjima i ponašanju (Bouillet i Uzelac, 2007; Resman, 2000).

Sa aspekta psihosocijalnog delovanja, savetovanje $u$ širem smislu određuje se kao "posebna metoda pružanja pomoći trenutno neuspješnim osobama u njihovom osobnom rastu, razvoju, sazrijevanju i prilagođavanju životnim uvjetima u svrhu osposobljavanja za samostalno rješavanje aktualnih i budućih problema" (Janković, 2004: 99). U užem smislu, savetovanje je moguće shvatiti kao "interpersonalni proces, kao neposrednu pomoć jedne osobe (savjetodavca) drugoj (klijentu)" (Resman, 2000: 42). Navedena određenja ukazuju na činjenicu da savetovanje treba razumeti kao proces u okviru kojeg savetnik ukazuje na različite perspektive i moguće pravce rešavanja određenog problema, a sve u cilju da korisnik savetovanja samostalno dođe do određenih uvida i izabere rešenje koje smatra najpogodnijim.

Sa aspekta pedagoškog delovanja, aktivnosti savetovanja označavane su različitim terminima (savetovanje, pedagoško savetovanje, pedagoško-savetodavni rad, razvojno-pedagoška delatnost, savetodavnovaspitni rad) (Hechler, 2010; Jurić, 2004; Mandić, 1986; Trnavac, 1996, Resman, 2000; Silov, 2000), pri čemu se savetovanje posmatralo kao faktor pedagoškog delovanja, odnosno kao vaspitno sredstvo koje omogućava da svaka ličnost maksimalno razvije svoje sposobnosti i kapacitete (Hechler, 2010). To znači da savetovanje predstavlja i proces poučavanja o tome kako da korisnik savetovanja savlada svoje teškoće i pronađe vlastita rešenja (Corey, 2004), te se može posmatrati kao oblik učenja (Hechler, 2010). Navedena određenja ukazuju na kompleksnost i specifičnost savetovanjakao profesionalne delatnosti, što implicira potrebu sagledavanja pretpostavki efikasnog savetodavnog rada. U tom smislu, u daljem tekstu će biti dat osvrt na osnovne karakteristike i ciljeve savetovanja, te razmatrani faktori koji su od ključnog značaja za uspešno realizovanje savetodavnog procesa. 


\section{Karakteristike i ciljevi savetovanja}

Proces savetovanja podrazumeva primenu principa mentalnog zdravlja, psiholoških principa i principa drugih društvenih nauka kroz kognitivne, afektivne i bihejvioralne intervencije u cilju blagostanja, ličnog razvoja, karijernog vođenja ili pak ispravljanja patologije (Gladding, 2012).

U ovom određenju naglašavaju se sledeće karakteristike savetovanja.

- Savetovanje se bavi blagostanjem, ličnim rastom i razvojem, što podrazumeva interakciju sa drugim ljudima. Proces savetovanja uključuje intrapersonalne i interpersonalne probleme povezane sa pronalaženjem smisla života i prilagođavanjem školi, radnom mestu, novom mestu življenja i sl.

- Savetovanje obično podrazumeva rad sa osobama koje imaju situacione ili razvojne poteškoće koje zahtevaju pomoć u vidu prilagođavanja ili sanacije. Ovakve teškoće uglovnom zahtevaju vremenski kraće savetodavno delovanje, ali - zavisno od specifičnosti određene poteškoće - može trajati i duže vreme.

- Savetovanje crpi svoja znanja iz različitih teorijskih pristupa i može biti primenjeno u radu sa pojedincima, porodicama i grupama.

- Savetovanje može biti razvojno ili interventno, što zavisi od toga da li je problem razvojni ili situacioni (Gladding, 2012).

Uzmajući u obzir varijacije teorijskih pristupa koji stoje u osnovi savetodavne delatnosti, postoji velika raznolikost u ciljevima koji se žele postići savetovanjem. Neki od ciljeva koji su implicitno ili eksplicitno naglašeni u različitim teorijskim pristupima jesu:

- samouvid: razumevanje nastajanja emocionalnih teškoća, povećanje kontrole nad mislima i emocijama;

- samosvest: uvid u sopstvene misli i osećanja i opažanje tuđih misli o nama;

- samoprihvatanje: razvoj pozitivnog stava prema sebi;

- samoaktuelizacija: razvoj usmerenosti na ispunjavanje vlastitih potencijala;

- rešavanje problema: ukazivanje na moguća rešenja određenog problema, usvajanje opštih kompetencija za rešavanje problema;

- psihološka edukacija: građenje mogućnosti da osoba usvaja znanja i veštine kojima će razumeti i kontrolisati vlastito ponašanje;

- sticanje socijalnih veština: sticanje i korišćenje socijanih veština poput kontrole besa, asertivnosti, nenasilne komunikacije i sl. 
- ognitivna promena: modifikacija iracionalih stavova i ponašanja koji su povezani sa (auto)destuktivnim ponašanjem;

- bihejvioralna promena: modifikacija neprihvatljivih obrazaca ponašanja;

- sistemska promena: prihvatanje promene u skladu sa pravilima funkcionisanja određenog sistema;

- osnaživanje: rad na veštinama, osvešćivanju i znanju koje će pomoći osobama da se suprotstave socijalnim nejednakostima;

- restitucija: pomoć osobama da isprave štetu načinjenu ranijim (auto) destuktivnim postupcima (McLeod, 2001).

S obzirom da je tokom procesa savetovanja teško obuhvatiti sve navedene ciljeve, postavljanje prioritetnih ciljeva savetovanja najčešće proizilazi iz teorijskog (terapeutskog) pristupa koji je savetniku najprihvatljiviji. Tako će kod savetnika psihodinamskog usmerenja akcenat biti na samouvidu, a kod bihejvioralno usmerenih savetnika na bihejvioralnoj promeni (McLeod, 2001). Karakteristike i ciljevi savetovanja zavise, pored teorijskog pristupa, i od toga da li je savetovanje zasnovano na direktivnom odnosu između savetnika i subjekta savetovanja u kojem savetnik provodi promene prema svom stručnom nahođenju, ili je zasnovano na nedirektivnom odnosu između savetnika i subjekta savetovanja koji podrazumeva aktivnu ulogu korisnika savetovanja $\mathrm{u}$ rešavanju problema (Janković, 2004). Naime, u procesu savetovanja koje je zasnovano na nedirektivnom odnosu, ključna karakteristika savetovanja je sloboda izbora odlučivanja u izboru alternativnih rešenja. To znači da savetnik ukazuje na potencijalne odgovore na poteškoće (dileme, pitanja, ponašanja) u kojima se osoba našla, te se moguća rešenja problema postavljaju kao alternative na osnovu kojih korisnik savetovanja vrši izbor i odlučuje o prihvatanju/neprihvatanju ponuđenih alternativa za prevazilaženje problema. Pritom je važno imati u vidu da savetovanje podrazumeva proces u kojem savetnik radi s korisnikom savetovanja, a ne za korisnika savetovanja (Ajduković i Cajvert, 2001), jer cilj savetovanja jeste osnaživanje pojedinaca ili grupa da svojim aktivnim delovanjem promene svoje životne situacije i unaprede svoje resurse u susretu sa zahtevima okoline.

Takođe, u relevantnoj literaturi (Nelson-Jones, 2007) ističe se da se ciljevi savetovanja mogu razmatrati kroz dva usmerenja: 1) ciljevi usmereni na ublažavanje slabosti i teškoća (kurativno/interventno savetovanje) i 2) ciljevi usmereni na rast i razvoj (razvojno savetovanje). U svakom slučaju, 
cilj savetovanja je menjanje ljudi u pozitivnom smeru, pri čemu pozitivna promena može biti vidljiva, kako u izvršavanju razvojnih zadataka, tako i u prevladavanju nekih nerazvojnih/akcedentnih poteškoća.

\section{Faktori uspešnog savetovanja}

$\mathrm{Na}$ efikasnost savetodavnog procesa utiču brojni faktori koji su determinisani društvenim, socijalnim, institucionalnim i personalnim specifičnostima. Ipak, ključni faktori uspešnog savetovanja jesu, s jedne strane, korisnik savetovanja, tj. pojedinac ili grupa sa svim svojim potrebama, motivima, očekivanjima i ciljevima, i, s druge, savetnik, tj. stručnjak sa svojim osobinama ličnosti, znanjima i veštinama. Pritom je bitno da efikasno savetodavno delovanje nije moguće bez uspostaljanja pozitivne emocionalne klime i adekvatnog odnosa između savetnika i korisnika savetovanja.

\section{Korisnik savetovanja}

Evidentna je činjenica da pojedinci ili grupe svakodnevno nailaze na veće ili manje probleme u svom ličnom ili profesionalnom životu, te da na različite načine reaguju na date poteškoće. Neke osobe uspevaju da na adekvatan način prevladaju problemske i stresne situacije, dok druge nemaju dovoljno razvijene mehanizme za prevazilaženje takvih situacija, te se javlja potreba za savetovanjem kao vidom profesionalne pomoći i podrške usmerene ka osnaživanju korisnika savetovanja da se na efikasan i delotvoran način izbore sa određenim problemima. Za početak je najvažnije da savetnik dođe do saznanja o tome koje su potrebe korisnika savetovanja. Iako su potrebe korisnika savetovanja tj. razlozi traženja savetodavne pomoći brojni i različiti, u relevantnoj literaturi (Janković, 2004: 28-33) ističe se da ih je moguće razvrstati u sledeće grupe.

1. Zadovoljavanje potrebe za komunikacijom - Potreba za komunikacijom je jedna od osnovnih ljudskih potreba i njeno nezadovoljavanje može dovesti do negativnih posledica. Nažalost, zadovoljavanje ove potrebe u uslovima opšte otuđenosti u savremenim uslovima života sve je teže. Strah od otkrivanja slabosti, kao i velika potreba za samopotvrđivanjem, neminovno uslovljavaju zatvaranje pojedinca čak i u odnosu na najbližu porodicu i prijatelje. Takvo zatvaranje u sebe dovodi do sve veće usamljenosti, a ona povećava distancu od okoline i tako se 
formira začarani krug iz kojeg je teško izaći. Takva izolacija onemogućava iskren i otvoren dijalog a samim tim i zadovoljavanje potrebe za bliskošću i otvorenom komunikacijom.

2. Lični problemi - Stalna napetost ljude veoma opterećuje i iz tog razloga oni sve češće dolaze u stanje preopterećenosti i nesigurnosti iz kojeg traže izlaz. Veliki broj ljudi će izlaz potražiti u izolaciji i traženju sebe. Samo nezadovoljstvo sobom je posledica različitih unutrašnjih i spoljašnjih pritisaka, nemogućnosti zadovoljavanja velikog broja potreba, neispunjenim ličnim očekivanjima. Međutim, i bez velikih kriza i problema, u svakodnevnom životu savremenog čoveka javljaju se trenuci krize, umora, nemogućnosti da se ostvari ono što je možda ostvarivo, što deluje obeshrabrujuće i izaziva sumnju u sopstvene potencijale. Vrlo često su to i problemi koji nastaju zbog neispunjavanja određenih uloga, organizacije ličnog i profesionalnog života, ili, ako je reč o deci/učenicima, zbog školskog neuspeha i problema uspostavljanja adekvatnih vršnjačkih odnosa.

3. Nezadovoljstvo okolinom - Problemi ove grupe se u procesu savetovanja najčešće sreću, ne samo zato što je lakše govoriti o tome šta druge osobe rade pogrešno, već i zato što je mnogo lakše procenjivati nekog drugog a ne sebe. Samo mali broj hipersenzibilnih osoba u ovakvoj situaciji preispituje najpre svoje postupke i eventualne greške. Najčešći problemi iz ove grupe odnose se na partnerske i porodične nesporazume. U ovakvim situacijama često nije dovoljno izolovano rešavanje problema, već je potrebno sagledavati stanje na različitim nivoima. Stoga uvođenje značajnih drugih osoba u proces savetovanja može biti vrlo korisno, jer je efikasnost prevazilaženja određenog problema često nemoguća bez uključivanja bliskih osoba (npr. partner, roditelji i drugi članovi porodice) koje su deo razvojnog okruženja korisnika savetovanja.

4. Potvrda ispravnosti ličnih postupaka - Veoma često korisnici savetovanja postaju osobe koje su zbog nekih životnih teškoća počele sumnjati u sebe, ali neretko i one koje imaju potrebu da neko potvrdi ispravnost njihovih stavova i mišljenja. Međutim, savetnik nema ulogu sudije nego stručnjaka koji treba da pruži pomoć i podršku korisniku savetovanja da sam dođe do spoznaje o vlastitim percepcijama i stavovima. Ovde se, takođe, nalaze i korisnici savetovanja koji su našli rešenje za određeni problem, ali nisu u potpunosti sigurni da je to rešenje najbolje. To su vrlo često osobe koje iz određenih razloga imaju imperativ savršenstva pa se stalno proveravaju, preispitaju svoje odluke. U ovakvim slučajevima 
suština savetodavnog rada je u tome da korisnici savetovanja postanu zadovoljni sobom i svojim odlukama. Sa ovakvim osobama je dobro raditi na njihovim komunikacijskim kompetencijama kako bi izbegli da, usled svoje opsednutosti savršenstvom, dolaze u konfliktne situacije sa bliskim osobama.

5. Posebne teškoće i problemi - Ovo je vrlo specifična grupa problema zato što se korisnik savetovanja suočava sa time da se mora prilagoditi posebnim životnim uslovima, ili izboriti sa nekim specifičnim situacijama koje ugrožavaju lični identitet i integritet. Reč je najčešće o osobama koje su se suočile sa problemima delinkventnog ponašanja, bolestima zavisnosti i sl. Iako je jasno da se ovim problemima moraju baviti posebna, specijalizovana savetovališta, činjenica je da će se i stručnjaci u različitim institucijama koje nisu usko usmerene samo na savetovanje (kao što su, naprimer, vaspitno-obrazovne institucije) suočavati sa situacijama u kojima treba da obavljaju savetodavni rad sa osobama koje imaju ovakve probleme. To znači da stručnjaci/profesionalci različitih profila (pedagog, psiholog, defektolog, socijalni radnik) treba da poseduju ključna znanja iz oblasti savetodavnog rada sa osobama sa ovakvim poteškoćama kako bi na adekvatan način mogli da im pruže podršku ili da ih, ukoliko problem prevazilazi kompetencije određenog stručnjaka, blagovremeno usmere na specijalizovane institucije.

Osim sagledavanja potreba korisnika savetovanja, veoma je važno sagledati i pitanje njihove motivacije za ulazak u proces savetovanja. Ovo pitanje je, pre svega, bitno zbog mogućeg otpora korisnika savetovanja prema aktivnom učešću u savetodavnom procesu i suočavanju sa potencijalnim problemima, što može u značajnoj meri da osujeti uspešnost savetovanja. U tom smislu, posebno je značajno saznanje o tome da li korisnik savetovanja samoinicijativno traži stručnu podršku ili je inicijativa za savetodavni rad potekla sa neke druge strane. Najčešće je motivacija za savetovanjem na visokom nivou u slučaju da osoba sama inicira proces savetovanja, jer shvata da ima problem i da joj treba pomoć, opterećena je situacijom i intenzivno reaguje na to što joj se događa. $U$ ovom slučaju, otpor prema procesu savetovanja uglavnom nije prisutan jer sam subjekt savetovanja želi da radi na prevazilaženju određenog problema. S druge strane, ukoliko iniciranje procesa savetovanja daje neko iz uže ili šire sredine, može doći do situacije da korisnik savetovanja i njegova okolina ne percipiraju problem na isti način, te proces savetovanja može biti doživljen kao pritisak i nepravda, što dovodi do pružanja otpora, 
izbegavanja razgovora, menjanja teme i sl.

Takođe je važno razmotriti da li je reč o unutrašnjoj motivaciji ili je reč o deklarisanoj, verbalizovanoj motivisanosti koja ponekad ni izdaleka nije u skladu s njenim stvarnim nivoom. Osobe u određenim problemskim situacijama često verbalizuju visok nivo motivisanosti i visoke ciljeve jer znaju da će to stručnjaci i socijalno okruženje nagraditi na različite načine (priznanjem, statusom, pružanjem veće pomoći i slično), ali iza tih izjava može biti jedva primetna motivisanost koja može biti neutralisana već pri prvom suočavanju sa problemom ili njegovim rešavanjem. U skladu sa tim, stručnjaci (Frankl, 2007; Janković, 2004; Kecmanović, 1975) navode različite probleme koji su u vezi sa nivoom motivisanosti korisnika savetovanja.

Jedan od problema proizilazi iz pretpostavke o postojanju motivacije za rešavanjem određenog problema samim tim što je neko zatražio razgovor sa stručnjakom i spreman je da razgovara o svojim poteškoćama. Međutim, neretko se dešava da potencijalni korisnici savetovanja nisu spremni da se suoče sa određenim problemima, već jednostavno žele da sa nekim porazgovaraju o svojim poteškoćama, dilemama, i na taj način ,ventiliraju“, isprazne nakupljene negativne emocije. Takođe, dešava se da korisnici savetovanja dođu sa jasno uočenom idejom o potrebi rešavanja problema i promene trenutnog stanja, ali da im se nakon razgovora o problemu (koji uglavnom dovodi do osećaja olakšanja i smanjenja emocionalne napetosti) učini daleko težim menjati svoju situaciju nego i dalje živeti s problemom na koji su se već u određenom smislu i navikli. Jednostavno rečeno, u ovakvim situacijama proces savetovanja ne doživljava se kao način za stvarnu promenu, već kao mogućnost da osoba oseti olakšanje u razgovoru s nekim ko će je dovoljno pažljivo slušati (Janković, 2004).

Drugi značajan problem proizilazi iz činjenice da motivacija za savetovanjem, uz kognitivni i emocionalni, obuhvata i konativni nivo, bez kojeg nema stvarne i celovite promene. Naime, iako je svesnost o postojanju problema veoma važan početni korak, on ne podrazumeva uvek i spremnost na promenu, pogotovu ukoliko posledice promene mogu uticati na bitna područja funkcionisanja korisnika savetovanja, kao i na njegov odnos sa bliskim osobama iz najužeg okruženja. Takođe, treba imati u vidu da je nivo motivacije za promenom u značajnoj meri određen intenzitetom i širinom problema koji je opteretio neku osobu i/ili njenu celokupnu porodicu, odnosno određenu grupu. Ukoliko je problem egzistencijalne prirode, akutan i tako intenzivan da izaziva nelagodu i stres, a dovoljno 
vidljiv da ga je moguće uočiti u svim njegovim aspektima, onda je to najčešće dovoljan motiv za pokretanje i vrlo temeljnih i složenih procesa promena. Konačno, nivo motivacije osobe koja je u fokusu intervencije $u$ savetodavnom procesu zavisi i od toga koliko joj privlačnim i ostvarivim izgledaju mogući ishodi rada na problemu. Nedovoljno privlačni rezultati napora na rešavanju problema mogu ubrzo dovesti do pada motivacije, što će imati za posledicu slabije zalaganje u nastavku procesa savetovanja. Ovakvo stanje može da izazove povratno negativno delovanje na motivaciju, čime se pokreće krug negativne akceleracije koji dovodi do stalnog opadanja nivoa motivisanosti i konačnog odustajanja od procesa savetovanja (Frankl, 2007).

Pored svega navedenog, važno je da efikasnost procesa savetovanja zavisi od toga da li je korisnik savetovanja otvoren prema okolini, da li je spreman da prihvati pomoć i, najvažnije, da li je spreman i sposoban za unutrašnje promene - promene u percepciji sebe i okoline, doživljavanju odnosa s drugima, emocionalnom reagovanju na unutrašnje i spoljašnje podražaje, kao i u pogledu ponašanja i celokupnog odnosa prema okolini (Kecmanović, 1975). Takođe, treba imati u vidu da korisnici savetovanja pripadaju različitim socijalnim i društvenim grupama, kao što su porodica, šira rodbinska zajednica, škola, susedstvo, razna udruženja, kolege, prijatelji itd. U skladu s tom pripadnošću određenom socijalnom entitetu u okviru različitih konteksta, oni prihvataju i odgovarajuće uloge na različitim nivoima. Činjenica je da u procesu pružanja savetodavne pomoći ne mogu biti obuhvaćeni svi socijalni konteksti i nivoi u kojima funkcioniše korisnik savetovanja. S obzirom da definisanje prostora i širine savetodavnog delovanja ima veliki uticaj na celokupan proces i ishod savetovanja, veoma je važno razmotriti nivo težine i širine problema koji se pokušava razrešiti, potom broj osoba koji su posredno ili neposredno involvirani u problem, kao i njihovu motivisanost za učestvovanje u procesu savetovanja. U idealnom slučaju, odluka o tome da li će u proces rešavanja problema biti uključen samo jedan učesnik ili veći broj ljudi treba da bude rezultat zajedničke procene korisnika savetovanja i stručnjaka.

\section{Stručnjak - savetnik}

Jedna od ključnih pretpostavki uspešnog savetovanja odnosi se na profesionalnost i celokupnu ličnost savetnika. Savetnikje stručna osoba koja primenjuje različite metode savetovanja sa ciljem osnaživanja korisnika 
savetovanja u procesu traženja optimalnog rešenja za određeni problem. Pritom je važno da sama činjenica da je neko stekao zvanje savetnika nije garancija njegove kompetentnosti niti efikasnosti savetodavnog rada, što implicira potrebu permanentnog rada na osnaživanju ličnih i profesionalnih svojstva koje se očekuju od kompetentnog stručnjaka - savetnika.

Pod kompetentnim savetnikom smatra se onaj koji ima sposobnost da, u cilju postizanja vidljivih rezultata u procesu savetovanja, koristi svoje profesionalne i lične kapacitete (znanja, veštine i sposobnosti), ali i kapacitete, odnosno resurse i podsticaje iz svog okruženja. Takođe, kompetentan savetnik ima kontrolu nad sobom i svojim ponašanjem, dobro se oseća u svojoj ulozi, i samim tim doprinosi da se i korisnik savetovanja dobro oseća i prihvati sebe. Posebno značajan segment profesionalne kompetentnosti savetnika odnosi se na visok nivo stručnog znanja, odnosno adekvatnog obrazovanja u različitim aspektima.

Naime, efikasno savetodavno delovanje moguće je samo ukoliko su zadovoljeni visoki kriterijumi niza međusobno povezanih nauka (psihologija, pedagogija, socijalni rad, socijalna psihijatrija, andragogija i druge), teorijskih polazišta i na njima zasnovanih pristupa $u$ radu $\mathrm{s}$ pojedincem, parom, porodicom, malim i velikim grupama. Tome treba dodati i poznavanje i korišćenje kvantitativne i kvalitativne metodologije društvenih istraživanja, kao i primenu saznajnih i iskustvenih tekovina timskog rada, grupnog rada, rada s porodicom, superviziju i evaluaciju. U svakom slučaju, presudan faktor u savetodavnom radu jesu znanja i veštine, mada ih nije uvek lako iskazati kao činjenicu ili dokazati rezultatima delovanja u području razrešavanja određenih psiho-socijalnih ili vaspitno-obrazovnih problema. U ovom kontekstu, zanimljiva je skala kompetentnosti koja nudi pet stupnjeva znanja, odnosno kompetentnosti/ nekompetentnosti.

1. Nesvesna nekompetentnost - Ovde je reč o neznanju kojeg osoba nije ni svesna. Osoba ne zna da ne zna. Ulazeći u rešavanje složenog problema, za šta su potrebni znanje ili veština, nesvestan svog neznanja, stručnjak može problem učiniti daleko većim nego što je bio pre njegove intervencije.

2. Svesna nekompetentnost - Svako je neznanje veliki nedostatak, pogotovo kada je u pitanju stručnjak, ali je ova vrsta ipak manje opasna od prethodne jer omogućava uvid a samim tim i učenje ili vežbu, zavisno od toga da li je reč o teoretskom znanju ili veštini.

3. Svesna kompetentnost - Odnosi se na ona znanja kojih je osoba svesna 
i može ih u svakom trenutku uspešno upotrebiti. To je najveći i najviše korišćeni deo svih znanja.

4. Nesvesna kompetentnost - Ovaj nivo predstavlja ona znanja ili veštine koje osoba poseduje, ali ih zaboravlja. Ne zna da zna.

5. Svesno nesvesna kompetentnost - Odnosi se na one sadržaje koje znamo da ne znamo da ih znamo. Tu je reč o znanjima ili veštinama koje nismo posebno savladali, nisu nam poznate, ali ćemo ih, nađemo li se u prilici, realizovati putem ostalih svojih znanja (prema: Janković, 2004: 21-22).

Znanje viđeno na ovaj način predstavlja se kao vrlo neodređena kategorija koja zahteva stalnu pažnju, ne u smislu procenjivanja jer ga je očito vrlo teško proceniti, već u smislu potrebe da stručnjak osvesti ona znanja koja poseduje a da to i ne zna, te da postane svestan da su mu određena područja nepoznata ili nedovoljno poznata. Za podršku ovom procesu najpogodnija je supervizija, koja, kada je vođena dovoljno suptilno i nedirektivno, omogućuje superviziranim stručnjacima da spontano i postupno uoče i shvate do tada nedostupna područja svojih znanja i veština (Ajduković i Cajvert, 2001; Grauwe \& Carron, 2007; Janković, 2004). Vrlo je verovatno da će savetnik koji poseduje stručne kompetencije imati osećaj zadovoljstva sobom, svojim pozivom, ali da će ujedno izgraditi i atmosferu u kojoj će i sami korisnici savetovanja doživeti osećaj zadovoljstva i, samim tim, biti spremniji i motivisaniji za rešavanje problema.

Pored toga što se od savetnika očekuje da stručne kompetencije stavi u funkciju svog delovanja, neophodno je da poseduje i određene socijalne $i$ komunikacijske kompetencije, jer je suština savetodavnog delovanja usmerena upravo na uspostavljanje odnosa i komunikacije sa korisnicima savetovanja. Pritom je značajno da uspostavljanje adekvatnog odnosa u procesu savetovanja zahteva, s jedne strane, prisustvo empatije koja podrazumeva sposobnost razumevanja tuđih osećanja i sagledavanja problema iz druge perspektive, ali, s druge strane, i prisustvo asertivnosti koja podrazumeva sposobnost izražavanja sopstvenih misli, osećanja i uverenja na direktan, iskren i adekvatan način, uvažavajući pri tome prava drugih (Goleman, 2010).

Pored stručnih, socijalnih i komunikacijskih kompetencija, stručnjak/savetnik treba da poseduje i određena lična svojstva, to jest lične osobine koje će pomoći da savetnik bude pozitivan model svojim korisnicima. U tom smislu, a na osnovu rezultata brojnih empirijskih istraživanja, u relevatnoj literaturi (Corey, 2004) su izdvojene osobine 
koje odlikuju dobrog savetnika. Naime, dobri savetnici imaju identitet, poštuju i cene sebe, otvoreni su za promene, prave odluke koje su životno orijentisane, imaju razvijen smisao za humor, spremni su da priznaju svoje greške, poštuju različitosti koje proizilaze iz različitih religijskih opredeljenja, socijalnih klasa, rase, seksualne orijentacije i sl, imaju iskren interes za dobrobit drugih, imaju dobre interpersonalne veštine, crpe zadovoljstvo iz svog posla, sposobni su da održavaju ravnotežu u svom privatnom i profesionalnom životu. Da bi navedene osobine postale zaista deo ličnosti savetnika, neophodno je stalno samoprocenjivanje i preispitivanje svog delovanja, odnosno „lociranje“ vlastitih slabosti i eventualnih nedostataka u radu (Laklija i sar., 2011). Takođe, razvijanje svesti o sebi pruža osnovu da se na adekvatan način aktiviraju unutrašnje snage potrebne za suočavanje sa brojnim profesionalnim izazovima koji su svojstveni procesu savetovanja (Jalom, 2011).

Neki autori (Corey, 2004) zastupaju stanovište da savetnici treba i sami da imaju lično iskustvo korisnika savetovanja, jer proces samoistraživanja i razvijanja svesti o sebi može pomoći da bolje razumeju i osobe koje savetuju. Takođe, ističe se i značaj razvijanja svesti o sopstvenim životnim vrednostima, te svesti o tome kako one utiču na njihov savetodavni rad. S obzirom da savetnik nije vrednosno neutralan i da su metode savetodavnog rada često izraz i njegove životne filozofije, to može uzrokovati određene probleme ukoliko radi sa korisnikom savetovanja koji ima drugačije životne vrednosti i drugačiji stav prema nekim osetljivim pitanjima (religija, seksualna orijentacija i sl). S druge strane, korisnici savetovanja često žele da znaju kakav je savetnikov stav prema nekim pitanjima kako bi mogli da preispitaju svoja gledišta. Takođe, dobar savetnik treba da uvidi i svoje stavove i uverenja, znanja i veštine u radu sa kulturalno različitim korisnicima savetovanja. To znači da savetnik treba da bude otvoren za različitosti i spreman za vođenje multikulturalnog savetovanja (Corey, 2004).

U skladu sa navedenim, važno je da, pored značaja motivisanosti korisnika savetovanja, nivo motivacije savetnika ima veliki uticaj na efikasnost procesa savetovanja. Činjenica je da savetnik teško može da sakrije nizak nivo sopstvene motivacije, a korisnik savetovanja to može shvatiti kao poruku o nemogućnosti rešavanja problema, njegovom nerazumevanju ili neprihvatanju, što može imati negativne reperkusije ne samo na nivo motivacije korisnika savetovanja, nego i na njegovu sliku o sebi, na samopoštovanje i samopouzdanje. Takođe, ukoliko su glavni 
motivi savetnika uglavnom lični (materijalni, statusni ili strukovni), odnosno nedovoljno usmereni na dobrobit korisnika, ishod procesa savetovanja može biti negativan. U tom smislu, u literaturi (Janković, 2004) se naglašava da nivo i kvalitet motivacije stručnjaka ima jednako važno mesto u procesu savetovanja kao i pristupi, metode, tehnike ili intervencije koje će biti primenjene. U svakom slučaju, savetnik treba da pokaže spremnost da uđe u blizak odnos sa korisnicima savetovanja, što zahteva njegovu sposobnost da sagleda svoj nivo motivacije i eventualne sopstvene otpore koje ima prema procesu savetovanja ili samom korisniku savetovanja.

\section{Zaključak}

Savetovanje ne podrazumeva davanje gotovih saveta u rešavanju nekog konkretnog problema, već uspostavljanje pozitivne emocionalne klime i takvih interpersonalnih odnosa koji pomažu korisniku savetovanja u ličnom sazrevanju i napredovanju. To znači da savetovanje ne daje model rešenja, već potpomaže oslobađanje potencijala ličnosti koji su blokirani. Stoga je veoma bitno da savetnik ima sposobnost za građenje i unapređivanje kvalitetnih odnosa sa korisnicima savetovanja, te da na taj način omogućuje uslove za kvalitetnu interakciju na svim nivoima.

Takođe, za uspostavljanje dobrog odnosa između savetnika i korisnika savetovanja veoma je važan izbor optimalnog pristupa u savetodavnom radu. Iako izbor adekvatnog pristupa zavisi od složenosti, vrste, uzroka, trajanja i drugih odrednica određenog problema, kao posebno delotvoran pokazao se Rodžersov nedirektivni pristup (Rodžers, 1985), koji zahteva da savetnik bude neposredan, da vodi razgovor tako da sagovornik ne gubi svoje "ja", da oseti unutrašnji svet sagovornika, kao i da iskaže prihvatanje i poštovanje sagovornika, a ne samo površnu sentimentalnost. Stoga je tokom formiranja odnosa sa korisnikom savetovanja važno voditi računa o elementima interpersonalne komunikacije (Reardon, 1998; Hartley, 1999), što uključuje neverbalne znakove, povratnu informaciju, adekvatno postavljanje pitanja, reflektovanje osećanja, aktivno slušanje, samootkrivanje, parafraziranje itd. Posebno je važno uspostaviti pozitivnu, podržavajuću klimu i odnos poverenja koji će korisniku savetovanja pružati osećaj zadovoljstva, prihvaćenosti i sigurnosti u savetodavnom rocesu. 


\title{
CHARACTERISTICS AND KEY FACTORS OF THE EFFICIENT COUNSELLING WORK
}

\author{
SUMMARY
}

Abstract: The paper points to the complexity and specificity of counselling as a profession, and emphasizes the importance of considering assumptions of an efficient counselling work. In this sense, the article is an overview of the basic characteristics and goals of counselling as a process aimed at empowering individuals and groups to change their life situations and improve their resources by their active functioning. A special emphasis is placed on the analysis of two factors that are crucial for the effectiveness of the counselling work: a counselling beneficiary, i.e. an individual or a group with all their needs, motivations, expectations and goals, and the counsellor, i.e. an expert with his/her personality traits, knowledge and skills. Thereby it is emphasized that the efficient counselling is not possible without establishing a positive emotional climate and an appropriate relationship between the counsellor and the beneficiary. Bearing in mind that the counselling does not provide model solutions, but helps releasing of the personality potentials which are blocked, the conclusion points out an importance of choosing the most appropriate approach in the counselling work, as well as the importance of establishing a supportive atmosphere that will provide to the beneficiary a sense of satisfaction, acceptance and safety in the counselling process.

Key words: counselling, counselling beneficiary, counsellor, counselling competencies.

\section{Literatura}

Ajduković, M. i Cajvert, Lj. (2001). Supervizija psihosocijalnog rada kao specifični oblik profesionalnog razvoja stručnjaka u sustavu socijalne skrbi, Ljetopis studijskog centra socijalnog rada, 8 (2), 195-214.

Bouillet, D. i Uzelac, S. (2007). Osnove socijalne pedagogije. Zagreb: Školska knjiga.

Corey, G. (2004). Teorija i praksa psihološkog savjetovanja i psihoterapije. Jastrebarsko: Naklada Slap.

Frankl, V. (2007). Nečujan vapaj za smislom- psihoterapija i humanizam. Beograd: IP Žarko Albulj.

Gladding, S. (2012). Counseling: A Comprehensive Profession (7th 
edition). N.J.: Pearson /Merrill/ Prentice Hall.

Goleman, D. (2010). Socijalna inteligencija. Beograd: Geopoetika.

Grauwe, A. \& Carron, G. (2007). Reforming school supervision for quality improvement. Paris: UNESCO.

Hartley, P. (1999). Interpersonal Communication. London: Routledge.

Hechler, O. (2010). Pedagoško savjetovanje - teorija i praksa odgojnog sredstva. Zagreb: Erudita.

Jalom, I. (2011). Cari psihoterapije. Novi Sad: Psihopolis.

Janković, J. (2004). Savjetovanje u psihosocijalnom radu, Zagreb: Nacionalna Sveučilišna knjižnica.

Jurić, V. (2004). Metodika rada školskog pedagoga. Zagreb: Školska knjiga.

Kecmanović, D. (1975). Socijalna psihijatrija. Sarajevo: Svjetlost.

Laklija, M., Kolega, M., Božić, T. i Mesić, M. (2011). Supervizijski stil i komunikacijski procesi u superviziji iz perspective supervizora. Ljetopis socijalnog rada, 18(2), 365-382.

Mandić, P. (1986). Savjetodavni vaspitni rad. Sarajevo: Svjetlost, Zavod za udžbenike i nastavna sredstva.

McLeod, J. (2001). An introduction to counseling. Buckingham: Open University Press.

Nelson-Jones, R. (2007). Praktične vještine u psihološkom savjetovanju $i$ pomaganju. Jastrebarsko: Naklada Slap.

Reardon, K. K. (1998). Interpersonalna komunikacija - Gdje se misli susreću. Zagreb: Alineja.

Resman, M. (2000). Savjetodavni rad u vrtiću i školi. Zagreb: Hrvatskopedagoško-književni zbor.

Rodžers, K. (1985). Kako postati ličnost. Beograd: Nolit.

Silov, M. (2000). Smisao, cilj i zadaci razvojne djelatnosti pedagoga stručnih suradnika. U: Pedagozi - stručni suradnici u inovacijskom vrtiću i školi (42-53). Zagreb: Hrvatski pedagoško-književni zbor.

Trnavac, N. (1996). Pedagog u školi. Beograd: Učiteljski fakultet. 